\title{
Marg-o mìr-e kūdakān dar İrān. Ravand-hā va šā Heș-hā (1335-1400). Tehrān, SCI, 1382/2003, 212 p. [Mortalité des enfants en Iran. Processus et indicateurs (1956-2021)]
}

Marie Ladier-Fouladi

\section{(2) OpenEdition}

Édition électronique

URL : http://journals.openedition.org/abstractairanica/1675

ISSN : 1961-960X

Éditeur :

CNRS (UMR 7528 Mondes iraniens et indiens), Éditions de l'IFRI

Édition imprimée

Date de publication : 15 mai 2005

ISSN : 0240-8910

Référence électronique

Marie Ladier-Fouladi, « Marg-o mìr-e kūdakān dar İrān. Ravand-hā va šāheș-hā (1335-1400). Tehrān, SCl, 1382/2003, 212 p. [Mortalité des enfants en Iran. Processus et indicateurs (1956-2021)] », Abstracta Iranica [En ligne], Volume 26 | 2005, document 411, mis en ligne le 07 décembre 2005, consulté le 25 septembre 2020. URL : http://journals.openedition.org/abstractairanica/1675

Ce document a été généré automatiquement le 25 septembre 2020.

Tous droits réservés 


\title{
Marg-o mīr-e kūdakān dar İrān. Ravand-hā va šāHeș-hā (1335-1400). Tehrān, SCI, 1382/2003, 212 p. [Mortalité des enfants en Iran. Processus et indicateurs (1956-2021)]
}

\author{
Marie Ladier-Fouladi
}

Il s'agit d'un document de grande importance dans la mesure où pour la première fois en Iran, une série de tables estimatives de mortalité par sexe ont été établies pour une période de 65 ans allant de 1956 à 2021. Ces tables présentant plusieurs indicateurs de mortalité par âge et par sexe, ont pu être constituées grâce aux multiples données démographiques produites en Iran depuis 1956, et en employant des méthodes indirectes. En se fondant sur l'évolution démographique et l'état sanitaire actuel du pays et à l'aide de quelques hypothèses, il a été également possible de faire diverses projections et par-là de constituer des tables de mortalité pour les 20 années à venir. Désormais, pour la période 1956 à 2021, on connaît, à chaque année civile, notamment les taux de mortalité et l'espérance de vie, pour chaque sexe et pour les enfants de 0, 1 et 5 ans, puis pour les individus âgés de 10 à 80 ans. Ainsi on peut suivre l'évolution de la mortalité en Iran, dans le passé, au cours des cinq dernières décennies, et dans le futur proche. 
INDEX

Thèmes : 12.1. Iran

Mots-clés : Statistiques, Mortalité infantile

Keywords : Statistics, Infant mortality

AUTEURS

MARIE LADIER-FOULADI

CNRS - Paris 